\title{
Telework during COVID-19 outbreak: Impact on mental health among Italian workers
}

\author{
Vincenzo Bertino ${ }^{1}$, Veronica Nisticò ${ }^{2,3}$, Armando D’Agostino ${ }^{2,4}$, Alberto Priori ${ }^{2,3,5}$, Orsola Gambini ${ }^{2,3,4}$, Benedetta

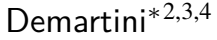 \\ ${ }^{1}$ Department of Mental Health and Addiction Services, Niguarda Hospital, Milan, Italy \\ ${ }^{2}$ Department of Health Sciences, University of Milan, Milan, Italy \\ 3 "Aldo Ravelli" Research Center for Neurotechnology and Experimental Brain Therapeutics, University of Milan, Milan, Italy \\ ${ }^{4}$ Psychiatry Unit, San Paolo Hospital, Milan, Italy \\ ${ }^{5}$ Neurology Unit, San Paolo Hospital, Milan, Italy
}

Received: November 18, 2020

DOI: $10.5430 /$ ijh.v7n2p29
Accepted: March 30, 2021

Online Published: October 15, 2021

\begin{abstract}
Objective: The outbreak of COVID-19 lead to an uptake of telework worldwide. We evaluated the prevalence of psychiatric symptoms, potential risks, and protective factors, across a sample of Italian workers that converted to teleworking.

Methods: 804 participants completed an online survey, including sociodemographic information (current work routine, home environment and clinical history) and the psychometric scales "Depression, Anxiety and Stress Scale - 21 items" and "Insomnia Severity Index."

Results: $30 \%$ of participants presented pathological levels of depression, $20.8 \%$ of anxiety, $30.7 \%$ of stress, and $5 \%$ appeared to suffer from insomnia. Prevalence was higher in respondents with psychological and physical frailties, greater social isolation or inadequate working spaces. However, telework itself was broadly appreciated and did not seem to be directly associated with increased psychiatric symptoms, which were exacerbated instead by COVID-19-related stress or by constitutional and social determinants of health.

Conclusions: Authorities should promote adequate measures to guarantee a healthy approach to teleworking.
\end{abstract}

Key Words: Work psychology, Occupational medicine, Teleworking, COVID-19, Stress, Anxiety, Depression

\section{INTRODUCTION}

The first cases of a new strand of atypical pneumonia, caused by a betacoronavirus, were detected in the Chinese city of Wuhan at the end of 2019. The new disease was named severe acute respiratory syndrome coronavirus 2 (SARS-CoV-2) or coronavirus disease 2019 (COVID-19). COVID-19 quickly spread to several countries worldwide and the World Health Organization officially declared it a pandemic on March 11th 2020. At the moment of writing, Italy is one of the most affected countries in the world, with more than 2.6 million cases and over 91,000 deaths. In order to halt and slow the outbreak, the Italian authorities ordered a severe lockdown of the country at the start of March 2020. Apart from the direct health consequences of the virus, the COVID-19 pandemic has had a major impact on the way people live and work, particularly once telework was strongly encouraged whenever possible. Telework may be defined as a new way of working, which includes any kind of arrangements where workers

\footnotetext{
*Correspondence: Benedetta Demartini; Email: benedettademartini@ gmail.com; Address: Department of Health Sciences, University of Milan, Milan, Italy.
} 
work remotely and that requires the use of information and communication technology (ICT), such as laptops, mobile phones and the internet. ${ }^{[1]}$ Teleworkers may be home-based, or they may work from any other location other than their employer's premises, using ICT on a regular basis. Teleworking arrangements were originally aimed at increasing the productivity and job satisfaction among workers, who were given greater control over their time and place of work. On top of this, further gains were expected from potential savings in office costs and decreased pollution due to less commuting. During the lockdown, a large proportion of Italian workers (about $40 \%$ ) were suddenly required to switch to home-based teleworking, ${ }^{[2]}$ even though Italy was one of the European countries with the lowest prevalence of telework (about 7\%) at the time. ${ }^{[1]}$ Prior to the COVID-19 outbreak there was limited research on the mental health impact of teleworking. However, some studies had already identified several psychological benefits and risks associated with it. On the one hand, some research suggested that telework had the potential for improving work-life balance, thanks to more opportunities to adjust working conditions to personal situations, less travel stress and work-life conflict. ${ }^{[3,4]}$ Others found that remote working was correlated with an increased likelihood of blurring of work boundaries, work stress, social isolation and anxiety. ${ }^{[1]}$ In addition to these telework-related outcomes, the Italian population now had to cope with the psychological distress from the COVID-19 outbreak and subsequent lockdown, ${ }^{[5]}$ similarly to what was observed in the same period in many other countries. ${ }^{[6-9]}$

In light of the above background, the main aim of the present study is to evaluate the prevalence of specific psychiatric symptoms (stress, anxiety, depression, sleeping disturbances) across a sample of Italian workers converted to telework during the COVID-19 outbreak in Italy. Secondly, we aim to identify potential risks and protective factors contributing to the development of the above-mentioned psychiatric symptoms in our sample. Our results can help public health and labor authorities evaluate the tradeoffs of teleworking in terms of mental wellbeing and work-life balance.

\section{Methods}

The present study is based on a cross-sectional survey, built from an anonymous online questionnaire. We used a snowball sampling strategy to recruit a population-based sample of workers who experienced teleworking in Italy during the COVID-19 outbreak. Data collection took place between May $20^{t h}$ and May $24^{\text {th }}$ 2020. All participants signed an online informed consent form before starting to fill in the questionnaire. The study was reviewed and approved by the local Ethics Committee. The online questionnaire collected sociodemographic and clinical information and retrieved information about home environment and work routine.

We created the following variables: (i) "Age;" (ii) "Gender;" (iii) "Education;" (iv) "Residential environment;" (v) "House size;" (vi) "Number of cohabitants;" (vii) "Partner in the house;" (viii) "Children 0-11 at home;" (ix) "Children 12-17 at home;" (x) "Employment type;" (xi) "Work field;" (xii) "Weeks teleworking;" (xiii) "Movements from home while teleworking;" (xiv) "Hours a day spent teleworking;" (xv) "Frequency of personal contacts while teleworking;" (xvi) "Past mental illness;" (xvii) "Current mental illness;" (xviii) "Current physical illness;" (ix) "Disability." Moreover, four variables were created to assess the participants' evaluation of their experience with telework: (i) "Telework routine," asking participants to compare their telework routine with their previous work routine (on a scale from 1, much worse, to 5, much better); (ii) "Telework evaluation," asking participants to globally evaluate their telework experience (on a scale from 0 , extremely negative, to 7 , extremely positive); (iii) “Telework replication," assessing participants' willingness to replicate the telework experience in the future; (iv) "Problems disengaging from internet," assessing whether participants faced difficulties in disconnecting from the internet for job-unrelated issues, such as online gambling or shopping. Participants were next asked to report positive and negative aspects of their teleworking experiences, to be chosen from the list shown in Table 1. Finally, participants were asked to complete two questionnaires. The first is the Depression, Anxiety and Stress Scale-21 items (DASS-21). ${ }^{[10]}$ This is a strongly validated self-reported questionnaire, assessing depressive and anxiety symptoms. A Total Score was calculated as an index of general distress; moreover, three subscales' scores were calculated, as follows: (i) Stress, averaging items 1, 6, 8, 11, 12, 14, 18; (ii) Anxiety, averaging items 2, 4, 7, 9, 15, 19, 20; (iii) Depression, averaging items 3, 5, 10, 13, 16, 17, 21. According to each subscale score, participants were labelled on a severity scale. Specifically, the subscale Stress score was divided into 0-7 (normal), 8-9 (mild), 10-12 (moderate), 13-16 (severe) and $\geq 17$ (extremely severe); the subscale Anxiety score was divided into 0-3 (normal), 4-5 (mild), 6-7 (moderate), 8-9 (severe) and $\geq 10$ (extremely severe); the subscale Depression score was divided into 0-4 (normal), 5-6 (mild), 7-10 (moderate), 11-13 (severe) and $\geq$ 14 (extremely severe). As a cutoff, we consider that participants falling in the category of "mild" or above presented pathological levels of stress, anxiety or depression. The second questionnaire is the Insomnia Severity Index (ISI). ${ }^{[1]}$ This is a 7-item self-report questionnaire investigating insomnia in the month before the assessment. Each item in the questionnaire is rated with a 5-point Likert scale. The 
total score is interpreted as follows: absence of insomnia (0-7); sub-threshold insomnia (8-14); moderate insomnia (15-21); and severe insomnia (22-28). Participants scoring 15 or above were considered in need of clinical attention. According to the results of the psychometric questionnaires, for each scale and subscale, a dichotomic variable was created, where participants scoring above the above-mentioned cutoffs were labelled Clinical, and participants scoring below were labelled Non Clinical.

Table 1. Positive and negative aspects of teleworking

\begin{tabular}{|c|c|}
\hline Positive aspects & $\mathbf{N}(\%)$ \\
\hline Flexibility in time management & $590(73.4)$ \\
\hline Less conflictual stress with colleagues & 158 (19.7) \\
\hline More time to devote to loved ones & $315(39.2)$ \\
\hline More time to devote to hobbies & $272(33.8)$ \\
\hline Increased work motivation and concentration & $105(13.1)$ \\
\hline Better spaces and/ or electronic equipment than in the office. & $74(9.2)$ \\
\hline Spontaneously reported: not commuting & $52(6.5)$ \\
\hline Spontaneously reported: better quality of lunch & $9(1.1)$ \\
\hline No positive aspects & $69(8.6)$ \\
\hline \multicolumn{2}{|l|}{ Negative aspects } \\
\hline Frequent interruptions & $209(26)$ \\
\hline Excessive remote control by employers & $40(5)$ \\
\hline Working in one's own spare time & 393 (48.89) \\
\hline Having to solve complex tasks on their own (e.g. unforeseen resolution, learning, tight deadlines etc.) & $117(14.6)$ \\
\hline Loss of motivation and concentration & $146(18.2)$ \\
\hline Increased conflict with cohabitants & $106(13.2)$ \\
\hline Lack of spaces and / or electronic equipment & $215(26.7)$ \\
\hline Spontaneously reported: lack of human interactions & $55(6.8)$ \\
\hline Spontaneously reported: overly sedentary work & $3(0.4)$ \\
\hline Spontaneously reported: difficulties due to the presence of children in the house & $16(2)$ \\
\hline Spontaneously reported: too much videoconferencing & $16(2)$ \\
\hline No negative aspects & $112(13.9)$ \\
\hline
\end{tabular}

\section{Statistical analysis}

Statistical analysis was performed using SPSS version 26 (Statistical Package for Social Science). The significance level was set at $\alpha=0.05$, and all tests are 2-tailed.

First, we calculated descriptive statistics for sociodemographic characteristics, for the teleworking assessment and for scale scores. Second, in order to assess the effect of sociodemographic characteristics on the psychometric assessment, we run the following analyses: (I) a series of Univariate ANOVA with each of the aforementioned sociodemographic variables as factors and the following dependent variables: (i) "Telework evaluation;" (ii) "Telework replication;" (iii) "Telework routine;" (vi) DASS-21 Total Score; (v) ISI Total Score. (II) multivariate ANOVA with the aforementioned sociodemographic variables as factors and the three subscales of the DASS-21 as dependent variables. We also used Bonferroni post-hoc analysis to verify specific differences between two of the groups defined by the sociodemographic variables. Finally, Pearson's correlation analysis allowed us to inves- tigate possible covariation between psychometric variables and teleworking variables.

\section{Results}

We retrieved a total of 804 valid questionnaires. All respondents were living in Italy at the time of testing. Sociodemographic and psychometric details are reported in Table 2; positive and negative aspects of the teleworking experience are shown in Table 1.

Women showed a higher level of anxiety than men in the DASS-21 subscale Anxiety $(p=.012)$. With respect to the educational level, participants with a bachelor degree scored higher in the DASS-21 Total Score than middle school and high school graduates (all $p<.05$ ). They also reported higher levels of stress $(p=.004)$ than middle or high school graduates, and of depression ( $p=.004)$ than high school graduates $(p=.003)$. Moreover, participants with a high school license or above showed higher levels of sleeping issues, evaluated through the ISI, than middle school graduates (all $p<.05$ ). 
Table 2. Descriptive statistics for sociodemographic and psychometric variables

\begin{tabular}{|c|c|c|}
\hline Variable & & Value \\
\hline Age, mean (SD) & & $39.2(9.5)$ \\
\hline \multirow{2}{*}{ Gender, N (\%) } & M & $322(40)$ \\
\hline & $\mathrm{F}$ & $482(60)$ \\
\hline \multirow{4}{*}{ Education, N (\%) } & middle school level & $9(1.1)$ \\
\hline & high school license & $145(18)$ \\
\hline & bachelor degree & $601(74.8)$ \\
\hline & doctoral degree & $49(6.1)$ \\
\hline \multirow{3}{*}{ Residential environment, N (\%) } & countryside & $19(2.4)$ \\
\hline & suburban & 187 (23.3) \\
\hline & urban & $598(74.4)$ \\
\hline \multirow{3}{*}{ House size, N (\%) } & $<50 \mathrm{~m}^{2}$ & $86(10.7)$ \\
\hline & $50-100 \mathrm{~m}^{2}$ & $453(56.3)$ \\
\hline & $>100 \mathrm{~m}^{2}$ & $265(33)$ \\
\hline \multirow{3}{*}{ Number of cohabitants, N (\%) } & 1 & $183(22.8)$ \\
\hline & 2 & $273(34)$ \\
\hline & 3 or more & $348(43.2)$ \\
\hline \multirow{2}{*}{ Partner in the house, $\mathrm{N}(\%)$} & no & $31539.2)$ \\
\hline & yes & 489 (60.8) \\
\hline \multirow{3}{*}{ Children 0-11 at home, N (\%) } & 0 & 610 (75.9) \\
\hline & 1 & $129(16)$ \\
\hline & 2 or more & $65(8.1)$ \\
\hline \multirow{3}{*}{ Children 12-17 at home, N (\%) } & 0 & $733(91.2)$ \\
\hline & 1 & $53(6.6)$ \\
\hline & 2 or more & $18(2.2)$ \\
\hline \multirow{3}{*}{ Employment type, N (\%) } & employee & 635 (79) \\
\hline & self-employed & 159 (19.8) \\
\hline & intern & $10(1.2)$ \\
\hline \multirow{13}{*}{ Work field, N (\%) } & finance, insurance and banking services & $57(7.1)$ \\
\hline & entrepreneurship and management & $50(6.2)$ \\
\hline & communication & $80(10)$ \\
\hline & education and research & $129(16)$ \\
\hline & public administration and law enforcement agencies & $43(5.3)$ \\
\hline & IT and telecommunication & $130(16.2)$ \\
\hline & health and social services & 104 (12.9) \\
\hline & real estate, design and fashion sectors & $25(3.1)$ \\
\hline & industry and trade & $55(6.8)$ \\
\hline & commercial services & $48(6)$ \\
\hline & legal and administrative services & $34(4.2)$ \\
\hline & entertainment and personal services & $18(2.2)$ \\
\hline & consulting services & 31 (3.9) \\
\hline \multirow{2}{*}{ Weeks teleworking, N (\%) } & 4 weeks or less & $70(7.5)$ \\
\hline & more than 4 weeks & $744(92.5)$ \\
\hline \multirow{4}{*}{$\begin{array}{l}\text { Movements from home while } \\
\text { teleworking, } \mathrm{N}(\%)\end{array}$} & never & $544(67.7)$ \\
\hline & less than once a week & 176 (21.9) \\
\hline & once a week & $58(7.2)$ \\
\hline & more than once a week & $26(3.2)$ \\
\hline
\end{tabular}

(Table continued on page 33) 
Table 2. (continued.)

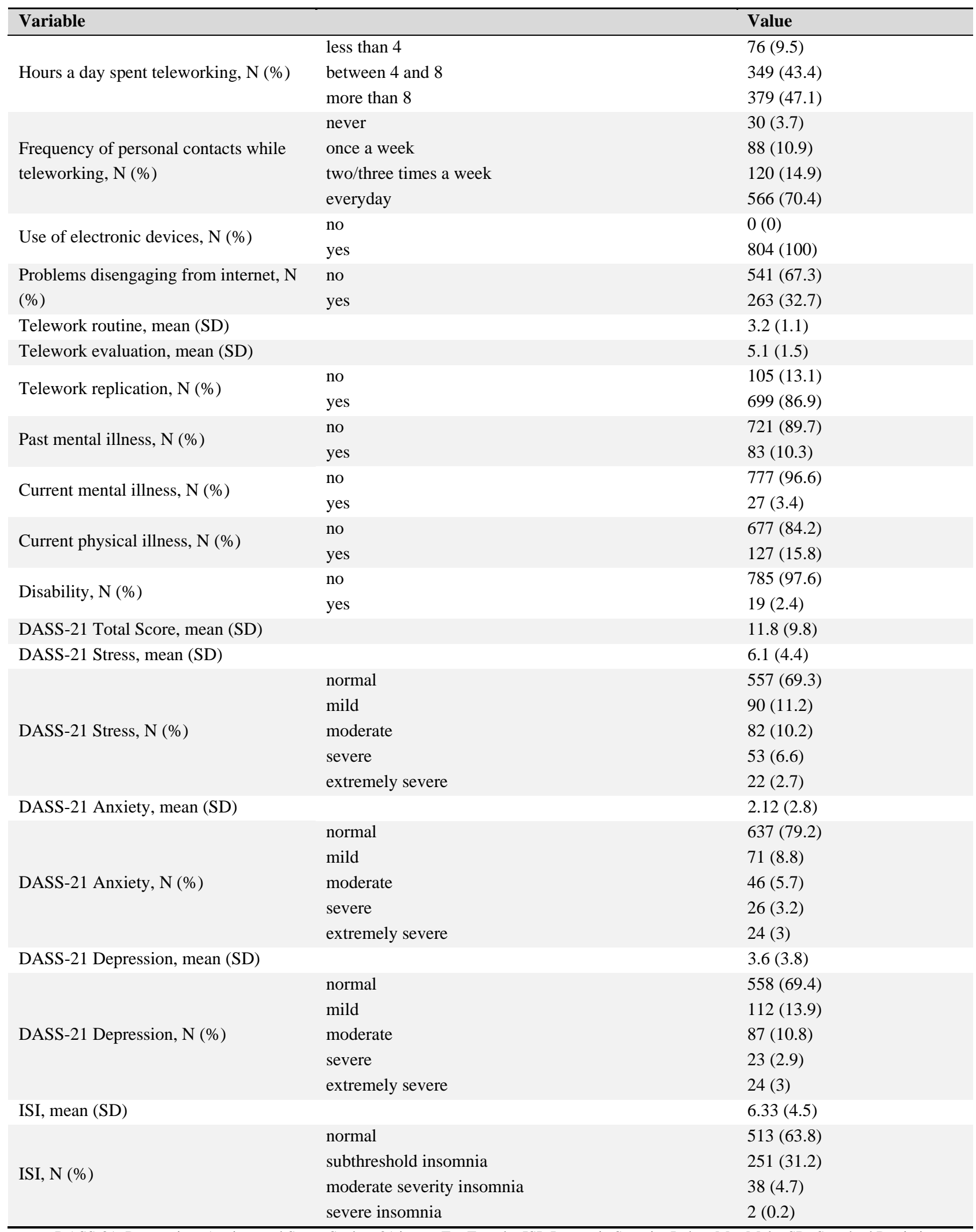

Note. DASS-21: Depression, Anxiety and Stress Scale - 21 items; F = Female; ISI: Insomnia Severity Index; M = Male; SD: Standard Deviation 
As regards house size, participants living in a house smaller than $50 \mathrm{~m}^{2}$ showed higher levels of stress, anxiety and depression (evaluated with the DASS-21, all $p<.001$ ) than participants living in a larger house. Moreover, participants living in a house between 50 and $100 \mathrm{~m}^{2}$ scored higher in the DASS-21 subscale Depression than those living in a house larger than $100 \mathrm{~m}^{2}(p=.006)$. The number of cohabitants in the house had a significant effect on several variables. First, participants sharing a house with two other cohabitants rated their teleworking routine higher than people living alone ( $p$ $=.050)$ and people living with three or more cohabitants $(p=.001)$. Second, participants living in houses with two cohabitants scored lower in the DASS-21 Total Score than participants living alone $(p=.020)$. In particular, participants living in a house with two, three or more cohabitants showed lower levels of depression than people living alone (all $p<$ .01). Third, participants living in houses with two other cohabitants showed lower levels of sleeping issues than people living alone and people living in houses with three or more cohabitants (all $p<.01$ ).

Participants living with their partner showed lower levels of anxiety and depression (evaluated with the DASS-21) than participants not living with their partner (all $p<.05$ ). Having children under 11 years of age at home had a significant effect on several variables. First, participants without children and those with two or more children rated the telework experience higher than participants with one child (all $p<$ $.05)$. Second, participants without children rated their teleworking routine higher than people with one child $(p<.001)$. Third, participants without children showed a lower level of stress than participants with one child $(p=.037)$. Also having children aged between 12 and 17 years at home had a positive and significant effect on stress levels $(p=.028)$.

With respect to the type of employment of each participant, we found that employees declared themselves willing to replicate the telework experience more than self-employed workers $(p=.11)$. Participants working in the field of "education and research" rated the telework experience and routine lower than participants working in most of other fields, and declared themselves less willing to replicate the telework experience than the majority of the other groups (all $p<.05$ ). They also showed higher levels of stress, anxiety and sleeping issues, as evaluated with the DASS-21 and the ISI, than most other groups (all $p<.05$ ). People teleworking for more than four weeks rated both the telework experience and routine higher than participants teleworking four weeks or fewer (all $p<.05$ ). However, in the DASS-21, they also showed higher levels of depression than participants teleworking four weeks or fewer $(p=.043)$.

The number of hours spent per day teleworking had a significant main effect on the DASS-21 subscale Stress $(p=.009)$ and ISI ( $p=.001)$; but in both cases no significant difference between groups remained after the Bonferroni correction (all $p>.5$ ). Participants having contacts with colleagues everyday rated the teleworking experience and routine higher and were more willing replicate the teleworking experience (all $p<.05$ ) than participants having less contacts with colleagues. The number of contacts with colleagues also had a negative effect on the DASS-21 subscale Depression ( $p=$ .005 ), though not after the Bonferroni correction (all $p>.5$ ).

Participants who received a psychiatric diagnosis in their lifetime showed higher levels of anxiety and sleeping issues than participants who did not ( $p=.036$ and $p<.001$ respectively), while participants with a psychiatric diagnosis at the time of testing showed a higher level of depression than participants otherwise $(p<.001)$. Also participants with a physical illness at the time of testing presented higher levels of anxiety ( $p=$ .016 ) and sleeping issues ( $p=.031$ ) than physically healthy participants, but participants with a certified disability had a significantly lower level of stress $(p=.033)$ than participants without. Further statistical details are reported in Tables 3 and 4.

\section{Correlational analysis}

The global judgement of participants on their teleworking experience (represented by the variable "Telework evaluation") resulted negatively correlated with the ISI score $(r=-.166)$, the DASS-21 Total score $(r=-.260)$ and its subscales Stress $(r=-.284)$, Anxiety $(r=-.139)$ and Depression $(r=-.236)$ (all $p<.001)$. This indicates that a better teleworking experience resulted in lower levels of stress, anxiety, depression and sleeping issues. The variable "Telework routine" was also negatively correlated with the scores in the ISI $(r=-.3)$ and the DASS-21 Total scores $(r=-.412)$, as well as in its subscales Stress $(r=-.44)$, Anxiety $(r=-.263)$ and Depression $(r=-.412)($ all $p<.001)$, suggesting that establishing an appropriate teleworking routine is associated with reduced levels of the aforementioned psychiatric symptoms.

Consistent with this finding, the variables "Telework evaluation" and "Telework routine" were positively correlated ( $r=$ $.655, p<.001)$, indicating that a global positive evaluation of teleworking was associated with the adjustment to a new positive routine. 
Table 3. Series of ANOVA with the sociodemographic variables as factors and teleworking-related variables as dependent variables

\begin{tabular}{|c|c|c|c|c|c|c|c|}
\hline & & \multicolumn{2}{|c|}{ Telework evaluation } & \multicolumn{2}{|c|}{ Telework replication } & \multicolumn{2}{|c|}{ Telework routine } \\
\hline & & $\begin{array}{l}\text { Mean } \\
\text { (SD) }\end{array}$ & $\begin{array}{l}F(p \\
\text { value })\end{array}$ & $\begin{array}{l}\text { Mean } \\
\text { (SD) }\end{array}$ & $\begin{array}{l}F(p \\
\text { value })\end{array}$ & $\begin{array}{l}\text { Mean } \\
\text { (SD) }\end{array}$ & $\begin{array}{l}F(p \\
\text { value })\end{array}$ \\
\hline \multirow{2}{*}{ Gender } & Male & $5.1(1.5)$ & \multirow{2}{*}{$0.3(.576)$} & $0.9(0.3)$ & \multirow{2}{*}{$0.5(.484)$} & $3.3(1)$ & \multirow{2}{*}{$0(.938)$} \\
\hline & Female & $5(1.5)$ & & $0.9(0.4)$ & & $3.2(1.1)$ & \\
\hline \multirow{4}{*}{ Education } & Middle school license & $6.3(1.1)$ & \multirow{4}{*}{$1.2(.319)$} & $0.9(0.3)$ & \multirow{4}{*}{$1.2(.318)$} & $3.7(1.4)$ & \multirow{4}{*}{$0.7(.532)$} \\
\hline & High school license & $5.2(1.6)$ & & $0.9(0.3)$ & & $3.3(1.2)$ & \\
\hline & Bachelor's degree & $5.1(1.5)$ & & $0.9(0.3)$ & & $3.2(1)$ & \\
\hline & Doctoral degree & $4.6(1.6)$ & & $0.9(0.4)$ & & $3.1(1.1)$ & \\
\hline \multirow{3}{*}{ Residential environment } & Countryside & $5(1.7)$ & \multirow{3}{*}{$0.2(.832)$} & $0.8(0.4)$ & \multirow{3}{*}{$1.4(.247)$} & $3.2(1)$ & \multirow{3}{*}{$0.3(.773)$} \\
\hline & Suburban country & $5.1(1.6)$ & & $0.8(0.4)$ & & $3.1(1)$ & \\
\hline & City & $5.1(1.5)$ & & $0.9(0.3)$ & & $3.2(1.1)$ & \\
\hline \multirow{3}{*}{ Size of the house } & $<50 \mathrm{~m}^{2}$ & $5(1.4)$ & \multirow{3}{*}{$0.7(.522)$} & $0.9(0.3)$ & \multirow{3}{*}{$0.3(.712)$} & $3.3(0.9)$ & \multirow{3}{*}{$0.1(.895)$} \\
\hline & $50-100 \mathrm{~m}^{2}$ & $5.2(1.5)$ & & $0.9(0.3)$ & & $3.2(1.1)$ & \\
\hline & $>100 \mathrm{~m}^{2}$ & $5(1.6)$ & & $0.8(0.3)$ & & $3.2(1.1)$ & \\
\hline \multirow{3}{*}{ Number of cohabitants } & 1 & $5(1.6)$ & \multirow{3}{*}{$2.3(.1)$} & $0.9(0.3)$ & \multirow{3}{*}{$1.2(.288)$} & $3.2(1)$ & \multirow{3}{*}{$3(.05)$} \\
\hline & 2 & $5.3(1.3)$ & & $0.9(0.3)$ & & $3.4(1)$ & \\
\hline & 3 or more & $4.9(1.6)$ & & $0.8(0.4)$ & & $3.1(1.2)$ & \\
\hline \multirow{2}{*}{ Partner in the house } & No & $5.1(1.5)$ & \multirow{2}{*}{$0.1(.763)$} & $0.9(0.3)$ & (947) & $3.3(1.1)$ & $10(166)$ \\
\hline & Yes & $5.1(1.5)$ & & $0.9(0.3)$ & $0(.04 /)$ & $3.2(1.1)$ & $1.5(.100)$ \\
\hline & 0 & $5.1(1.5)$ & & $0.9(0.3)$ & & $3.3(1)$ & \\
\hline Children (0-11 at home) & 1 & $4.7(1.8)$ & $3.1(.045)$ & $0.9(0.4)$ & $0.3(.765)$ & $2.8(1.2)$ & $3.1(.046)$ \\
\hline & 2 or more & $5.2(1.3)$ & & $0.9(0.3)$ & & $3.1(1.1)$ & \\
\hline & 0 & $5.1(1.5)$ & & $0.9(0.3)$ & & $3.2(1.1)$ & \\
\hline Children (12-17 at home) & 1 & $4.8(1.7)$ & $0.1(.894)$ & $0.8(0.4)$ & $0.3(.717)$ & $2.9(1.1)$ & $0.7(.52)$ \\
\hline & 2 or more & $5.1(2)$ & & $0.8(0.4)$ & & $3.4(1.5)$ & \\
\hline & Employee & $5.1(1.5)$ & & $0.9(0.3)$ & & $3.3(1.1)$ & \\
\hline Employment type & Self-employed & $4.9(1.6)$ & $1.2(.296)$ & $0.8(0.4)$ & $3(.05)$ & $3.1(1)$ & $1.4(.236)$ \\
\hline & Intern & $4.1(1.7)$ & & $0.7(0.5)$ & & $2.5(0.7)$ & \\
\hline & $\begin{array}{l}\text { Finance, insurance and banking } \\
\text { services }\end{array}$ & $5.3(1.3)$ & & $1(0.1)$ & & $3.3(1)$ & \\
\hline & Entrepreneurship and management & $5.3(1.3)$ & & $0.9(0.3)$ & & $3.4(0.9)$ & \\
\hline & Communication & $5.1(1.3)$ & & $0.9(0.3)$ & & $3.3(0.9)$ & \\
\hline & Education and research & $4.2(1.6)$ & & $0.7(0.5)$ & & $2.7(1)$ & \\
\hline & $\begin{array}{l}\text { Public administration and law } \\
\text { enforcement agencies }\end{array}$ & $4.9(1.9)$ & & $0.9(0.4)$ & & $3.2(1.3)$ & \\
\hline Work field & IT and telecommunication & $5.6(1.3)$ & $4.3(<$ & $1(0.2)$ & $5.2(<$ & $3.5(1)$ & $3.1(<$ \\
\hline 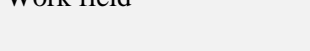 & Health and social services & $5(1.5)$ & $.001)$ & $0.8(0.4)$ & $.001)$ & $3.2(0.9)$ & $.001)$ \\
\hline & Real estate, design and fashion sectors & $5.2(1.5)$ & & $0.9(0.3)$ & & $3.2(1.1)$ & \\
\hline & Industry and trade & $5(1.7)$ & & $0.9(0.3)$ & & $3.2(1.2)$ & \\
\hline & Commercial services & $5.6(1.3)$ & & $0.9(0.3)$ & & $3.6(1.1)$ & \\
\hline & Legal and administrative services & $5.2(1.7)$ & & $0.9(0.3)$ & & $3.1(1.1)$ & \\
\hline & Entertainment and personal services & $5.1(1.2)$ & & $0.9(0.3)$ & & $3.2(0.9)$ & \\
\hline & Consulting services & $5.6(1.5)$ & & $0.9(0.3)$ & & $3.2(1.1)$ & \\
\hline
\end{tabular}

(Table continued on page 36) 
Table 3. (continued.)

\begin{tabular}{|c|c|c|c|c|c|c|c|}
\hline & & \multicolumn{2}{|c|}{ Telework evaluation } & \multicolumn{2}{|c|}{ Telework replication } & \multicolumn{2}{|c|}{ Telework routine } \\
\hline & & $\begin{array}{l}\text { Mean } \\
\text { (SD) }\end{array}$ & $\begin{array}{l}\text { F (p } \\
\text { value) }\end{array}$ & $\begin{array}{l}\text { Mean } \\
\text { (SD) }\end{array}$ & $\begin{array}{l}\text { Mean } \\
\text { (SD) }\end{array}$ & $\begin{array}{l}\text { F (p } \\
\text { value) }\end{array}$ & $\begin{array}{l}\text { Mean } \\
\text { (SD) }\end{array}$ \\
\hline \multirow{2}{*}{ Weeks teleworking } & 4 weeks or less & $4.3(1.6)$ & \multirow{2}{*}{$7.7(.006)$} & $0.8(0.4)$ & \multirow{2}{*}{$1.3(.253)$} & $2.7(0.8)$ & \multirow{2}{*}{$4.6(.003)$} \\
\hline & More than 4 weeks & $5.1(1.5)$ & & $0.9(0.3)$ & & $3.2(1.1)$ & \\
\hline \multirow{4}{*}{$\begin{array}{l}\text { Movements from home } \\
\text { while teleworking }\end{array}$} & Never & $5.1(1.6)$ & \multirow{4}{*}{$0.3(.837)$} & $0.9(0.3)$ & \multirow{4}{*}{$0.8(.52)$} & $3.2(1.1)$ & \multirow{4}{*}{$0.5(.701)$} \\
\hline & Less than once a week & $5.1(1.5)$ & & $0.9(0.3)$ & & $3.3(1)$ & \\
\hline & Once a week & $4.9(1.4)$ & & $0.9(0.3)$ & & $3.1(1.1)$ & \\
\hline & More than once a week & $5(1.5)$ & & $0.9(0.3)$ & & $3.1(1)$ & \\
\hline \multirow{3}{*}{$\begin{array}{l}\text { Hours a day spent } \\
\text { teleworking }\end{array}$} & Less than 4 & $4.4(1.9)$ & \multirow{3}{*}{$2.6(.078)$} & $0.8(0.4)$ & \multirow{3}{*}{$0.8(.445)$} & $2.6(1.1)$ & \multirow{3}{*}{$2.5(.087)$} \\
\hline & Between 4 and 8 & $5.1(1.3)$ & & $0.9(0.3)$ & & $3.2(1)$ & \\
\hline & More than 8 & $5.2(1.6)$ & & $0.9(0.3)$ & & $3.3(1.1)$ & \\
\hline \multirow{4}{*}{$\begin{array}{l}\text { Frequency of personal } \\
\text { contacts while teleworking }\end{array}$} & Never & 4.3 (1.9) & \multirow{4}{*}{$3.7(.012)$} & $0.7(0.5)$ & \multirow{4}{*}{$3.2(.024)$} & $2.7(1)$ & \multirow{4}{*}{$3.6(.013)$} \\
\hline & Once a week & $4.4(1.6)$ & & $0.7(0.4)$ & & $2.8(1)$ & \\
\hline & Two/three times a week & $4.8(1.6)$ & & $0.8(0.4)$ & & $2.9(1)$ & \\
\hline & Everyday & $5.3(1.4)$ & & $0.9(0.3)$ & & $3.4(1)$ & \\
\hline \multirow{2}{*}{ Past mental illness } & No & $5.1(1.5)$ & 0.04 & $0.9(0.3)$ & \multirow{2}{*}{$2.3(.129)$} & $3.2(1.1)$ & \multirow{2}{*}{$0.6(.45)$} \\
\hline & Yes & 5 (1.5) & $(.853)$ & $0.9(0.3)$ & & $3.2(1.2)$ & \\
\hline \multirow{2}{*}{ Current mental illness } & No & $5.1(1.5)$ & 0.02 & $0.9(0.3)$ & \multirow{2}{*}{$0.3(.606)$} & $3.2(1.1)$ & \multirow{2}{*}{$0.1(.785)$} \\
\hline & Yes & $5.2(1.7)$ & (.989) & $1(0.2)$ & & $3.4(1.1)$ & \\
\hline \multirow{2}{*}{ Current physical illness } & No & $5.1(1.5)$ & \multirow{2}{*}{$0.1(.699)$} & $0.9(0.3)$ & \multirow{2}{*}{$0.4(.523)$} & $3.2(1)$ & \multirow{2}{*}{$2(.159)$} \\
\hline & Yes & $5(1.8)$ & & $0.8(0.4)$ & & $3.1(1.2)$ & \\
\hline \multirow{2}{*}{ Disability } & No & $5.1(1.5)$ & $0.1(.732)$ & $0.9(0.3)$ & $0(.903)$ & $3.2(1.1)$ & $0.5(.464)$ \\
\hline & & $\begin{array}{l}\mathrm{R}^{2}=0.15 \\
\mathrm{R}^{2}=0.11\end{array}$ & (Adapted & $\begin{array}{l}\mathrm{R}^{2}=0.14 \\
\mathrm{R}^{2}=0.09\end{array}$ & (Adapted & $\begin{array}{l}\mathrm{R}^{2}=0.15 \\
\mathrm{R}^{2}=0.10\end{array}$ & ) (Adapted \\
\hline
\end{tabular}

Note. ISI: Insomnia Severity Index; SD: Standard Deviation

\section{Discussion}

To the best of our knowledge, this is the first study assessing the prevalence of specific psychiatric symptoms across a sample of people teleworking during the COVID-19 outbreak in Italy. Our findings showed that symptoms of depression, anxiety and stress, according to the DASS-21 scores, had a prevalence of respectively $30 \%, 20.8 \%$ and $30.7 \%$ in our sample. Moreover, according to the ISI scores, $5 \%$ of our sample appeared to suffer from insomnia. These levels of psychiatric symptomatology were negatively associated with the broader evaluation of teleworking in our sample, suggesting that finding a good teleworking routine helped participants to experience lower levels of stress, anxiety, depression and sleeping disturbances. The specific factors which prevented our respondents from appreciating their teleworking experience were living in a house smaller than $50 \mathrm{~m}^{2}$, living alone, and having to take care of a child younger than 11 years old On the contrary, having a larger house, living with a partner or with one or two housemates, and having frequent contacts with colleagues were protective factors against the onset of the aforementioned psychiatric symptoms and concurred in making participants willing to replicate the teleworking experience. Finally, participants working in the field of "education and research" not only judged their telework experience and routine much worse than participants working in other fields, but also showed higher levels of stress, anxiety and sleeping issues, as evaluated with the DASS-21 and the ISI scales.

The levels of depressive symptoms in our sample of teleworkers are comparable to those found in the general Italian population in the two months after the COVID-19 outbreaks. ${ }^{[5,12]}$ Contemporary research on the risk of depression around the world in the context of the COVID-19 outbreak has revealed a spread of outcomes. Concerning the Chinese population, Zhang et al. ${ }^{[13]}$ and Wang et al. ${ }^{[14]}$ observed a prevalence of depressive symptoms (34.7 and 30.3\% respectively); other studies reported either a higher $(48 \%)^{[8]}$ or a lower $(17 \%)^{[15,16]}$ prevalence. Similarly, data from Spain and Hong Kong showed lower levels than the ones we found (around 18\%-19\%). ${ }^{[7,9]}$ Several reasons could explain this 
variance. First, online surveys distributed via a snowball sampling strategy could lead to unbalanced and, therefore, not comparable samples. Second, different studies adopted different psychometric tests, implying possible differences in sensitivity and specificity.

In our sample, depression levels seem associated with some predisposing conditions that were not directly teleworkrelated, but that could have contributed to a less efficient adjustment to teleworking during the lockdown. First, current psychiatric disorders were frequently reported by respondents who scored higher for depression, revealing a substrate of increased psychological vulnerability. Second, living together with a partner represented a protective factor, similar to not living alone. This is consistent with previous studies showing that prolonged social isolation is associated with greater risk of depression, both in the context of teleworking and during the COVID-19 outbreak. ${ }^{[9,17,18]}$ Third, depression was associated with longer teleworking duration, potentially correlating with the threats of prolonged isolation. Moreover, workers with a bachelor's degree were more affected by depression, as well as those living in smaller households. This latter feature suggested that workplace conditions are important to preserve mental well-being.

Surprisingly, anxiety levels observed in our sample were quite similar to pre-epidemic anxiety rates $(25 \%)$ among home-based teleworkers. ${ }^{[1]}$ This finding is also in line with anxiety levels measured in the general population of other countries during the COVID-19 pandemic, ranging between $13 \%$ and $28 \% .^{[7-9,13,15,16]}$ Moreover, our data shows that anxious symptoms are associated with risk factors not directly related to teleworking. Firstly, anxiety was more frequent in women, in line with the general predominance of anxiety disorders among women. ${ }^{[19]}$ Secondly, anxious symptoms were more common among teleworkers who had previous episodes of mental disorder, revealing a long-term vulnerability to stressful events. Thirdly, having a physical disease was associated with higher levels of anxiety, a possible psychiatric manifestation of the underlying medical condition or, alternatively, as a consequence of a higher health concern in the context of the pandemic. In addition, teleworkers not living with a partner were more likely to be affected by anxiety, suggesting that a prolonged separation from companions, exacerbated by the restrictions imposed by the lockdown, represents a pro-anxious stimulus, as recently reported by Brooks et al. ${ }^{[6]}$ Furthermore, living in smaller houses correlated with a greater risk to develop anxiety manifestations. Therefore, we can speculate that, even if telework itself did not contribute directly to increase anxiety levels in our sample, the observed levels of anxiety could be driven by the emotional reaction to the ongoing outbreak and the confine- ment measures. It should also be mentioned that previous literature showed limited and contradictory findings about the relationship between teleworking and anxiety. On the one hand, a greater risk for anxiety during teleworking was correlated with more intense work, a tendency to work during free time, frequent interruptions and the use of electronic devices. ${ }^{[1,20]}$ On the other hand, teleworking appeared to reduce anxiety symptoms, depending on individual peculiarities and personality traits. ${ }^{[21]}$

In terms of stress, our sample approximately reported the same prevalence observed among teleworkers in a preepidemic survey. ${ }^{[22]}$ Our findings are also in line with stress levels found among the general population in Italy since the COVID-19 outbreak. ${ }^{[5]}$ In addition, other studies, conducted across the populations affected by the COVID-19 pandemic, found stress levels ranging between $8 \%$ and $70 \% .{ }^{[15,16]}$ Once more, this wide range can be due to different methodological choices, such as unbalanced samples and different instruments to screen for stress. All things considered, our sample did not allow us to distinguish to what extent stress was caused by either teleworking or the pandemic in general. However, we observed that stress is significantly associated with some risk factors that, although not telework-related, can potentially affect individuals' coping strategies in the context of the lockdown. For instance, being affected by disability led to increased levels of stress, in contrast with the general notion that teleworking may be beneficial for disabled workers. ${ }^{[23]}$ Our finding could be explained by the increased difficulties to access healthcare due to the lockdown, in case of disabilities requiring a regular follow-up, or by greater social isolation. With regards to socio-demographic determinants, stress was significantly elevated among participants with higher education, as well as those teleworking from small houses. Moreover, teleworkers with one child were more stressed and less able to adjust to the new teleworking routine than those with no children or with two or more children, similarly to what was already observed during the prior outbreak of equine influenza in Australia. ${ }^{[24]} \mathrm{Al}-$ though we can only speculate about this aspect, it seems that the lifestyle of parents with one child is particularly demanding, especially as children were permanently at home as a result of the lockdown. For all these reasons, we can hypothesize that stress levels were mostly related to the ongoing outbreak, rather than to teleworking itself. Previous literature has also been inconclusive. On the one hand, teleworking might be a source of stress, especially if associated with prolonged working hours, isolation, and difficulty in coping with computer technologies. ${ }^{[25-27]}$ On the other, teleworking seems to reduce stress, contributing to a better work-life balance. ${ }^{[25,28]}$ 
Table 4. Series of ANOVA with the sociodemographic variables as factors and psychometric variables as dependent variables

\begin{tabular}{|c|c|c|c|c|c|c|c|c|c|c|c|}
\hline & & \multicolumn{2}{|c|}{$\begin{array}{l}\text { DASS-21 Total } \\
\text { Score }\end{array}$} & \multicolumn{2}{|c|}{ DASS-21 Stress } & \multicolumn{2}{|c|}{ DASS-21Anxiety } & \multicolumn{2}{|c|}{$\begin{array}{l}\text { DASS-21 } \\
\text { Depression }\end{array}$} & \multicolumn{2}{|c|}{ ISI Total Score } \\
\hline & & $\begin{array}{l}\text { Mean } \\
\text { (SD) }\end{array}$ & $\begin{array}{l}F(p \\
\text { value })\end{array}$ & $\begin{array}{l}\text { Mean } \\
\text { (SD) }\end{array}$ & $\begin{array}{l}\text { F ( } p \\
\text { value) }\end{array}$ & $\begin{array}{l}\text { Mean } \\
\text { (SD) }\end{array}$ & $\begin{array}{l}F(p \\
\text { value })\end{array}$ & $\begin{array}{l}\text { Mean } \\
\text { (SD) }\end{array}$ & $\begin{array}{l}F(p \\
\text { value })\end{array}$ & $\begin{array}{l}\text { Mean } \\
\text { (SD) }\end{array}$ & $\begin{array}{l}F(p \\
\text { value })\end{array}$ \\
\hline \multirow{2}{*}{ Gender } & Male & $11.1(10)$ & \multirow{2}{*}{$\begin{array}{l}2.1 \\
(.146)\end{array}$} & $5.8(4.5)$ & \multirow{2}{*}{$\begin{array}{l}1.8 \\
(.175)\end{array}$} & $1.8(2.8)$ & \multirow{2}{*}{$\begin{array}{l}6.3 \\
(.012)\end{array}$} & $3.6(3.9)$ & \multirow{2}{*}{$\begin{array}{l}0.1 \\
(.798)\end{array}$} & $6.1(4.6)$ & \multirow{2}{*}{$\begin{array}{l}1.6 \\
(.207)\end{array}$} \\
\hline & Female & $12.2(9.7)$ & & $6.3(4.4)$ & & $2.3(2.9)$ & & $3.6(3.8)$ & & $6.5(4.4)$ & \\
\hline \multirow{4}{*}{ Education } & Middle school license & $3.2(5.4)$ & \multirow{4}{*}{$\begin{array}{l}5 \\
(.002)\end{array}$} & $1.6(2.5)$ & \multirow{4}{*}{$\begin{array}{l}4.5 \\
(.004)\end{array}$} & $0.6(1)$ & \multirow{4}{*}{$\begin{array}{l}4.4 \\
(.004)\end{array}$} & $1.1(2.4)$ & \multirow{4}{*}{$\begin{array}{l}4.4 \\
(.004)\end{array}$} & $2(2.6)$ & \multirow{4}{*}{$\begin{array}{l}3.6 \\
(.013)\end{array}$} \\
\hline & High school license & $9.6(7.2)$ & & $5.1(3.9)$ & & $1.8(2.2)$ & & $2.7(2.4)$ & & $6.4(4.2)$ & \\
\hline & Bachelor's degree & $12.5(10.4)$ & & $6.3(4.6)$ & & $2.3(3)$ & & $3.9(4.2)$ & & $6.3(4.6)$ & \\
\hline & Doctoral degree & $11.2(8.6)$ & & $6.5(3.9)$ & & $1.5(2.6)$ & & 3.3 (3.9) & & $6.9(4.5)$ & \\
\hline \multirow{3}{*}{$\begin{array}{l}\text { Residential } \\
\text { environment }\end{array}$} & Countryside & $11.4(7.6)$ & \multirow{3}{*}{$\begin{array}{l}0.6 \\
(.545)\end{array}$} & $6.2(4.2)$ & \multirow{3}{*}{$\begin{array}{l}0.4 \\
(.665)\end{array}$} & $2.2(2.3)$ & \multirow{3}{*}{$\begin{array}{l}0.6 \\
(.577)\end{array}$} & $3(2.5)$ & \multirow{3}{*}{$\begin{array}{l}0.5 \\
(.617)\end{array}$} & $4.2(3.8)$ & \\
\hline & Suburban country & $10.6(8.8)$ & & $5.6(4.1)$ & & $1.9(2.4)$ & & $3.1(3.4)$ & & $6.5(4.2)$ & $\begin{array}{l}2.0 \\
(062)\end{array}$ \\
\hline & City & $12.2(10.1)$ & & $6.2(4.5)$ & & $2.2(3)$ & & $3.8(4)$ & & $6.4(4.6)$ & \\
\hline & $<50 \mathrm{mq}$ & $16.1(11.9)$ & 10.7 & $7.7(5.2)$ & & $3.1(3.9)$ & & $5.3(4.6)$ & 11.1 & $7(5.2)$ & \\
\hline house & $50-100 \mathrm{mq}$ & $11.7(9.5)$ & $(<.00$ & $6(4.2)$ & $(<.001)$ & $2(2.7)$ & $(.011)$ & 3.7 (3.8) & $(<.001$ & $6.2(4.3)$ & $2(.14)$ \\
\hline & $>100 \mathrm{mq}$ & $10.4(9.2)$ & 1) & $5.6(4.3)$ & & $1.9(2.6)$ & & $2.9(3.5)$ & ） & $6.2(4.5)$ & \\
\hline & 1 & $13.2(10.5)$ & & $6.3(4.4)$ & & $2.5(3.3)$ & & $4.4(4.3)$ & & $7.1(4.6)$ & \\
\hline Number of & 2 & $10.8(9.8)$ & $\begin{array}{l}3.7 \\
(024)\end{array}$ & $5.6(4.5)$ & $\begin{array}{l}2.6 \\
(074)\end{array}$ & $1.9(2.8)$ & $\begin{array}{l}2.7 \\
(07)\end{array}$ & $3.3(3.6)$ & $\begin{array}{l}3.5 \\
(031)\end{array}$ & $5.5(4)$ & $\begin{array}{l}3.4 \\
(035)\end{array}$ \\
\hline & 3 or more & $11.8(0.4)$ & & $6.3(4.4)$ & & $2.1(2.5)$ & & $3.4(3.7)$ & & $6.6(4.7)$ & \\
\hline Partner in & No & $13.4(10.5)$ & 6.6 & $6.3(4.4)$ & 1.2 & $2.5(3.2)$ & 4.2 & $4.5(4.3)$ & $13.7<<$ & $7(4.6)$ & 3.4 \\
\hline the house & Yes & $10.8(9.2)$ & $(.011)$ & $5.9(4.4)$ & $(.265)$ & $1.8(2.5)$ & $(.04)$ & $3(3.4)$ & $.001)$ & $5.9(4.4)$ & $(.067)$ \\
\hline & 0 & $11.9(10.1)$ & & $5.9(4.4)$ & & $2.2(3)$ & & $3.8(4)$ & & $6.3(4.4)$ & \\
\hline $\begin{array}{l}\text { Cnilaren } \\
0-11 \text { at home }\end{array}$ & 1 & $12.1(9)$ & $\begin{array}{l}1.2 \\
(29)\end{array}$ & $6.9(4.6)$ & 3.3 & $1.8(2.3)$ & 1.6 & $3.4(3.5)$ & 1 & $6.7(4.9)$ & $\begin{array}{l}1.1 \\
(337)\end{array}$ \\
\hline & 2 or more & $10(8)$ & & $5.8(4.3)$ & & $1.5(1.7)$ & & $2.7(3.3)$ & & $5.6(4.5)$ & \\
\hline & 0 & $12.1(9.9)$ & & $6.2(4.5)$ & & $2.2(2.9)$ & & 3.7 (3.9) & & $6.3(4.5)$ & \\
\hline Children & 1 & $9.4(8.7)$ & 2.7 & $5(3.8)$ & 3.6 & $1.7(2.6)$ & 232 & $2.6(3.6)$ & 0.9 & $6.5(4.5)$ & 1 \\
\hline home & 2 or more & $7.6(6.5)$ & $(.067)$ & $3.9(3.4)$ & $(.028)$ & $1.1(1.7)$ & $2.3(.1)$ & $2.6(2.3)$ & $(.389)$ & $5.2(4.1)$ & $(.384)$ \\
\hline & Yes & $10.9(9.4)$ & & $5.6(4.1)$ & & $2.1(2.8)$ & & $3.2(3.7)$ & & $6.2(4.4)$ & \\
\hline & Employee & $11.7(9.9)$ & & $6(4.5)$ & & $2.1(2.9)$ & & $3.6(3.8)$ & & $6.5(4.6)$ & \\
\hline Emproyment & Self-employed & $11.5(8.9)$ & $\begin{array}{l}1.2 \\
(293)\end{array}$ & $6.1(4.1)$ & $\begin{array}{l}1.1 \\
(319)\end{array}$ & $2(2.4)$ & $\begin{array}{l}0.4 \\
(659)\end{array}$ & $3.4(3.8)$ & 1.7 & $5.8(3.8)$ & 0.5 \\
\hline & Intern & $19.2(13.3)$ & & $8.6(5.1)$ & & $3.7(2.6)$ & & $6.9(7)$ & & $7.4(4.4)$ & \\
\hline & $\begin{array}{l}\text { Finance, insurance and } \\
\text { banking services }\end{array}$ & $12.3(8.4)$ & & $6.2(4.2)$ & & $2.2(2.5)$ & & $3.9(2.9)$ & & $6.6(4.4)$ & \\
\hline & $\begin{array}{l}\text { Entrepreneurship and } \\
\text { management }\end{array}$ & $12.5(13)$ & & $6(4.9)$ & & $2.4(4)$ & & $4.1(4.9)$ & & $6.2(3.9)$ & \\
\hline & Communication & $13.2(8.7)$ & & $7.2(4.2)$ & & $2.2(2.3)$ & & $3.9(3.6)$ & & $6.1(4.2)$ & \\
\hline & Education and research & $15.4(11.9)$ & & $7.8(4.9)$ & & $3.2(3.8)$ & & $4.6(4.5)$ & & $8.7(4.6)$ & \\
\hline & $\begin{array}{l}\text { Public administration and } \\
\text { law enforcement agencies }\end{array}$ & $13.1(10.3)$ & & $6.5(4.8)$ & & $2.5(2.4)$ & & $4.2(4.4)$ & & $7.3(4.9)$ & \\
\hline & IT and telecommunication & $10.2(8.3)$ & & $5.3(3.9)$ & & $1.6(2.1)$ & & $3.3(3.9)$ & & $5.8(4.2)$ & \\
\hline Work field & Health and social services; & $10.9(9.1)$ & 2.9 & $5.7(4.2)$ & 3.2 & $2.1(2.6)$ & 2.8 & $3(3.3)$ & 1.5 & $4.9(3.9)$ & $\begin{array}{l}4.8 \\
(<.001\end{array}$ \\
\hline & $\begin{array}{l}\text { Real estate, design and } \\
\text { fashion sectors }\end{array}$ & $11.24(8)$ & $(.001)$ & & $(<.001)$ & & $(.001)$ & & $(.125)$ & $6.4(4.7)$ & ) \\
\hline & Industry and trade & $11.1(10)$ & & $5.6(4.5)$ & & $1.9(2.8)$ & & $3.6(4)$ & & $6.6(5.3)$ & \\
\hline & Commercial services & $9.5(9.2)$ & & $5(4.4)$ & & $1.5(2.4)$ & & $\begin{array}{l}2.9 \\
(3.33)\end{array}$ & & $5.3(4.3)$ & \\
\hline & $\begin{array}{l}\text { Legal and administrative } \\
\text { services }\end{array}$ & $8.8(8.3)$ & & $4.5(4)$ & & $1.4(2.4)$ & & $2.9(3.4)$ & & $5.1(4.4)$ & \\
\hline & $\begin{array}{l}\text { Entertainment and } \\
\text { personal services }\end{array}$ & $9.3(7.1)$ & & $5.6(4.2)$ & & $1.2(1.5)$ & & $2.5(3)$ & & $6.7(4.6)$ & \\
\hline & Consulting services & $8.2(6.4)$ & & $4.5(3.2)$ & & $1.2(1.5)$ & & $2.5(3.1)$ & & $4.4(3)$ & \\
\hline
\end{tabular}


Table 4. (continued.)

\begin{tabular}{|c|c|c|c|c|c|c|c|c|c|c|c|}
\hline & & \multicolumn{2}{|c|}{$\begin{array}{l}\text { DASS-21 Total } \\
\text { Score }\end{array}$} & \multicolumn{2}{|c|}{ DASS-21 Stress } & \multicolumn{2}{|c|}{ DASS-21Anxiety } & \multicolumn{2}{|c|}{$\begin{array}{l}\text { DASS-21 } \\
\text { Depression }\end{array}$} & \multicolumn{2}{|c|}{ ISI Total Score } \\
\hline & & $\begin{array}{l}\text { Mean } \\
\text { (SD) }\end{array}$ & $\begin{array}{l}F(p \\
\text { value })\end{array}$ & $\begin{array}{l}\text { Mean } \\
\text { (SD) }\end{array}$ & $\begin{array}{l}\text { F ( } p \\
\text { value) }\end{array}$ & $\begin{array}{l}\text { Mean } \\
\text { (SD) }\end{array}$ & $\begin{array}{l}F(p \\
\text { value })\end{array}$ & $\begin{array}{l}\text { Mean } \\
\text { (SD) }\end{array}$ & $\begin{array}{l}F(p \\
\text { value })\end{array}$ & $\begin{array}{l}\text { Mean } \\
\text { (SD) }\end{array}$ & $\begin{array}{l}\text { F ( } p \\
\text { value })\end{array}$ \\
\hline \multirow{2}{*}{$\begin{array}{l}\text { Weeks } \\
\text { teleworking }\end{array}$} & 4 weeks or fewer & $10.3(10.6)$ & \multirow{2}{*}{$\begin{array}{l}2.8 \\
(.097)\end{array}$} & $5.4(4.1)$ & \multirow{2}{*}{$\begin{array}{l}1.5 \\
(.216)\end{array}$} & $2(3.3)$ & \multirow{2}{*}{$\begin{array}{l}1.1 \\
(.305)\end{array}$} & $2.9(4.1)$ & \multirow{2}{*}{$\begin{array}{l}4.1 \\
(.043)\end{array}$} & $5.8(4.6)$ & \multirow{2}{*}{$\begin{array}{l}0.4 \\
(.527)\end{array}$} \\
\hline & More than 4 weeks & $11.9(9.7)$ & & $6.1(4.4)$ & & $2.1(2.8)$ & & $3.7(3.8)$ & & $6.4(4.5)$ & \\
\hline \multirow{4}{*}{$\begin{array}{l}\text { Movements } \\
\text { from home } \\
\text { while } \\
\text { teleworking }\end{array}$} & Never & $11.7(9.8)$ & \multirow{4}{*}{$\begin{array}{l}2.2 \\
(.09)\end{array}$} & $6.1(4.4)$ & \multirow{4}{*}{$\begin{array}{l}2.2 \\
(.087)\end{array}$} & $2(2.7)$ & \multirow{4}{*}{$\begin{array}{l}2.5 \\
(.057)\end{array}$} & $3.6(3.8)$ & \multirow{4}{*}{$\begin{array}{l}1.3 \\
(.275)\end{array}$} & $6.3(4.6)$ & \multirow{4}{*}{$\begin{array}{l}1.4 \\
(.246)\end{array}$} \\
\hline & Less than once a week & $11.7(9.1)$ & & $6(4.1)$ & & $2.1(2.7)$ & & $3.6(3.7)$ & & $6.2(4.3)$ & \\
\hline & Once a week & $14.4(11.8)$ & & $7.2(5.3)$ & & $2.9(3.6)$ & & $4.3(4.4)$ & & $6.7(4)$ & \\
\hline & More than once a week & $8.3(9.3)$ & & $3.9(3.7)$ & & $2.2(3.5)$ & & $2.2(2.8)$ & & $6(4.5)$ & \\
\hline \multirow{3}{*}{$\begin{array}{l}\text { Hours a day } \\
\text { spent } \\
\text { teleworking }\end{array}$} & Less than 4 & $13.3(11.1)$ & \multirow{3}{*}{$\begin{array}{l}2.9 \\
(.055)\end{array}$} & $6.5(4.8)$ & \multirow{3}{*}{$\begin{array}{l}4.8 \\
(.009)\end{array}$} & $2.6(3.2)$ & \multirow{3}{*}{$\begin{array}{l}1.9 \\
(.152)\end{array}$} & $4.2(4.4)$ & \multirow{3}{*}{$\begin{array}{l}1.5 \\
(.23)\end{array}$} & $6.3(5.1)$ & \multirow{3}{*}{$\begin{array}{l}6.6 \\
(.001)\end{array}$} \\
\hline & Between 4 and 8 & $11.1(9.7)$ & & $5.6(4.2)$ & & $2(2.8)$ & & 3.5 (3.9) & & $6(4.3)$ & \\
\hline & More than 8 & $12.1(9.6)$ & & $6.3(4.5)$ & & $2.2(2.7)$ & & $3.6(3.6)$ & & $6.7(4.5)$ & \\
\hline \multirow{4}{*}{$\begin{array}{l}\text { Frequency } \\
\text { of personal } \\
\text { contacts } \\
\text { while } \\
\text { teleworking }\end{array}$} & Never & $14.5(14.1)$ & \multirow{4}{*}{$\begin{array}{l}2.1 \\
(.103)\end{array}$} & $6.3(4.9)$ & \multirow{4}{*}{$\begin{array}{l}0.3 \\
(.804)\end{array}$} & $3.1(4.5)$ & \multirow{4}{*}{$\begin{array}{l}2 \\
(.117)\end{array}$} & $5.1(5.4)$ & \multirow{4}{*}{$\begin{array}{l}4.4 \\
(.005)\end{array}$} & $5.9(4.9)$ & \multirow{4}{*}{$\begin{array}{l}0.6 \\
(.588)\end{array}$} \\
\hline & Once a week & $12.3(9.5)$ & & $6.5(4.1)$ & & $2.1(2.6)$ & & $3.7(4.2)$ & & $7(5)$ & \\
\hline & Two/three times a week & $13(10.2)$ & & $6.4(4.4)$ & & $2.5(3)$ & & $4.1(4.2)$ & & $6.5(4.3)$ & \\
\hline & Everyday & $11.3(9.5)$ & & $5.9(4.5)$ & & $2(2.7)$ & & $3.4(3.6)$ & & $6.2(4.4)$ & \\
\hline \multirow{2}{*}{$\begin{array}{l}\text { Past mental } \\
\text { illness }\end{array}$} & No & $11.4(9.6)$ & \multirow{2}{*}{$\begin{array}{l}2.9 \\
(.088)\end{array}$} & $6(4.4)$ & & $2(2.7)$ & 4.4 & $3.4(3.7)$ & 2.2 & $6(4.4)$ & 19.3 \\
\hline & Yes & $15.1(10.9)$ & & $6.9(4.2)$ & $(.263)$ & $3(3.3)$ & $(.036)$ & $5.1(4.7)$ & $(.137)$ & $9.1(4.7)$ & $\begin{array}{l}(<.001 \\
)\end{array}$ \\
\hline Current & No & $11.6(9.7)$ & 2.8 & $6(4.4)$ & 0.6 & $2.1(2.8)$ & 0.1 & 3.5 (3.7) & 10.2 & $6.2(4.4)$ & 0.1 \\
\hline $\begin{array}{l}\text { mental } \\
\text { illness }\end{array}$ & Yes & $16.9(12.2)$ & (.096) & $7.1(4.4)$ & $(.446)$ & $3(3.5)$ & (.809) & $6.8(5.5)$ & $(.001)$ & $8.9(5.5)$ & (.748) \\
\hline Current & No & $11.5(9.5)$ & 4.6 & $6(4.4)$ & 3.1 & $2(2.7)$ & 5.8 & 3.5 (3.7) & 2.7 & $6.1(4.4)$ & 4.7 \\
\hline $\begin{array}{l}\text { physical } \\
\text { illness }\end{array}$ & Yes & $13(11.2)$ & $(.032)$ & $6.5(4.5)$ & (.079) & $2.6(3.3)$ & $(.016)$ & $3.9(4.5)$ & $(.1)$ & $7.3(5)$ & $(.031)$ \\
\hline Disability & No & 11.9 (9.9) & 3.4 & $6.1(4.4)$ & 4.6 & $2.1(2.8)$ & 0.4 & 3.6 (3.9) & 3 & $6.3(4.5)$ & 1 \\
\hline Disabinty & Yes & $8.3(6.3)$ & $(.065)$ & 3.9 (3.3) & $(.033)$ & $1.8(2.1)$ & (.509) & $2.5(2.3)$ & $(.083)$ & $6.4(3.8)$ & $(.312)$ \\
\hline & & $\begin{array}{l}\mathrm{R}^{2}=0.172( \\
\left.\mathrm{R}^{2}=0.125\right)\end{array}$ & Hapted & $\begin{array}{l}\mathrm{R}^{2}=0.15 \mathrm{~S} \\
\mathrm{R}^{2}=0.111\end{array}$ & Idapted & $\begin{array}{l}\mathrm{R}^{2}=.138 \\
\mathrm{R}^{2}=0.08 \mathrm{~s}\end{array}$ & apted & $\begin{array}{l}\mathrm{R}^{2}=0.17 \\
\text { (Adapted } \\
0.126 \text { ) }\end{array}$ & & $\begin{array}{l}\mathrm{R}^{2}=0.18 \\
\text { (Adapted } \\
0.137 \text { ) }\end{array}$ & \\
\hline
\end{tabular}

Note. DASS-21: Depression. Anxiety and Stress Scale - 21 items; ISI: Insomnia Severity Index; SD: Standard Deviation

Insomnia rates did not seem to be particularly affected by teleworking in the course of the epidemic. In fact, the insomnia levels in our sample are similar to the prevalence among the general population before the outbreak, ${ }^{[29]}$ as well as to the figures detected in China during the COVID-19 outbreak. ${ }^{[15]}$ In our sample of teleworkers, insomnia affected more frequently participants who had previously suffered from a mental illness and those who were currently affected by a physical disease. These observations highlight the link between sleep quality and health conditions, including individual psychological vulnerability factors, since numerous disorders may interfere with sleep. We also found that a lower education attainment (up to middle school) as well as co-habitation were correlated with better sleep quality. Nevertheless, according to previous literature, teleworking may expose individuals to sleeping problems, possibly due to higher levels of supplemental work and work intensity, ${ }^{[1]}$ even though reduced commuting allows for longer sleeping hours. ${ }^{[30]}$

Importantly, our study showed that insomnia, depression, anxiety, and stress were significantly higher among teleworkers in "educational and research" occupations, which represented $16 \%$ of the whole sample. Dealing with pupils had already been recognized as one of the most frequent risk factors for work stress. ${ }^{[31]}$ Moreover, education is one of the fields with the lowest prevalence of regular home-based working arrangements. ${ }^{[1]}$ This leads us to suspect that the greater stress identified in this class of respondents may be associated with difficulties in converting to online teaching methods.

Turning to the risk of technology overuse (unrelated to home working), our findings showed that $33 \%$ of teleworkers struggled more than usual with disconnecting from the internet (e.g., shopping sites, social networks, news, etc.) or other electronic programs (e.g., video-games). We speculate that this finding may be associated with several risk conditions that were present in our sample. First of all, the use of electronic devices, which was reported by the totality of our sample, seems to be correlated with a greater risk of excessive and compulsive use of technologies in the context 
of teleworking. ${ }^{[1]}$ Secondly, anxiety, which may also have been exacerbated by the COVID-19-related threats, represents a risk factor for internet addiction and overuse of social networks. ${ }^{[8,32]}$ Thirdly, the lockdown itself could have contributed to a greater exposure to technology-based activities, due to movement restrictions and social isolation. In fact, previous studies found a spike in the consumptions of digital entertainment, especially online gaming, in the course of the COVID-19-related confinement. ${ }^{[33]}$

Finally, we want to emphasize that teleworking was widely appreciated within our sample. In fact, about $87 \%$ of respondents expressed the willingness to have access to this kind of working arrangement in future, especially among employees. Respondents who kept frequent social contacts with colleagues and those who were less affected by previous mental health conditions reported an improvement in their work routine. Greater flexibility in working schedules, more time to devote to loved ones and hobbies, decreased conflicts with colleagues and not commuting were the most frequent benefits of teleworking reported by our sample. Negative ratings were more common among participants who found it harder to adjust their routine to the new work settings. This difficulty seemed to correlate with teleworking periods shorter than a month, potentially because respondents did not have sufficient time to settle down into the new routine. Moreover, workers in the field of "education and research" reported a deterioration of their work routine, possibly as a result of specific field-related barriers. Some drawbacks were also frequently reported, such as working on free time, inadequate spaces or equipment, frequent interruptions, diminished motivation, and lower social interactions. About $13 \%$ of our sample also complained of increased conflicts with cohabitants, raising a warning about increased risks of domestic violence correlated with stay at home policies.

Our study has some limitations. The first limitation comes from the use of an online survey that did not allow the researchers to directly explain the aim of the study and to debrief the participants. Second, as we did not ask whether COVID-19 affected our respondents or their relatives, we could not assess its direct impact on mental health separate from teleworking. Third, our survey did not evaluate personality and psychological traits, despite their influence on coping strategies in stressful events. Fourth, we did not have a control group of people who were not subjected to teleworking during the lockdown: this made it harder to distinguish between psychiatric symptoms associated with teleworking and other stimuli related to the abnormal social and health situation during the pandemic. With respect to this point, two considerations should be done. First, it is possible that individuals who converted to telework had more secure occupations than those who could not do it. Among the latter were essential workers who had to continue attending their work place (i.e., health workers, groceries, drivers of public means of transportations, etc.) and workers who lost their jobs because of the pandemic. Therefore, although we focused our research on teleworkers only, it is important to state that other groups of workers might be at even higher risk of mental health problems. Second, since our research was focused on teleworking during the context of the COVID-19 pandemic, our results should not be generalized to teleworking in general. Future researchers should evaluate the mental health consequences of teleworking when implemented as a choice, rather than imposed for safety concerns.

In conclusion, our study showed that about a third of our sample manifested psychopathological symptoms while teleworking during the COVID-19 outbreak in Italy. However, telework itself did not seem to be directly associated with increased psychiatric symptoms, which were instead exacerbated by COVID-19-related stressful circumstances or by constitutional and social determinants of health. Going forward, authorities should promote adequate measures to guarantee a healthy approach to teleworking.

\section{Authors' CONTRIBUtions}

Dr. Vincenzo Bertino and Dr. Veronica Nisticò equally contributed to the study.

\section{CONFLICTS OF INTEREST DisClOSURE}

The authors declare that they have no competing interests.

\section{REFERENCES}

[1] Vargas-Llave O, Mandl I, Weber T. Telework and ICT-based mobile work: flexible working in the digital age. 2020.

[2] European Foundation for the Improvement of Living and Working Conditions (Eurofound) (2020) Living, working and COVID-19: first findings, April 2020

[3] Baltes BB, Briggs TE, Huff JW, et al. Flexible and compressed workweek schedules: A meta-analysis of their effects on workrelated criteria. Journal of Applied Psychology. 1999; 84(4): 496. https://doi .org/10.1037/0021-9010.84.4.496

[4] Grzywacz JG, Carlson DS, Shulkin S. Schedule flexibility and stress: Linking formal flexible arrangements and perceived flexibility to employee health. Community, Work and Family. 2008; 11(2): 199-214. https://doi.org/10.1080/13668800802024652

[5] Moccia L, Janiri D, Pepe M, et al. Affective temperament, attach- 
ment style, and the psychological impact of the COVID-19 outbreak: an early report on the Italian general population. Brain, Behavior, and Immunity. 2020; 87: 75-79. PMid:32325098. https: //doi.org/10.1016/j.bbi.2020.04.048

[6] Brooks SK, Webster RK, Smith LE, et al. The psychological impact of quarantine and how to reduce it: rapid review of the evidence. The Lancet. 2020; 395(10227): 912-920. https ://doi.org/10.101 6/S0140-6736(20) 30460-8

[7] Choi EPH, Hui BPH, Wan EYF. Depression and Anxiety in Hong Kong during COVID-19. International Journal of Environmental Research and Public Health. 2020; 17(10): 3740. PMid:32466251. https://doi.org/10.3390/ijerph17103740

[8] Gao J, Zheng P, Jia Y, et al. Mental health problems and social media exposure during COVID-19 outbreak. Plos One. 2020; 15(4): e0231924. PMid:32298385. https ://doi.org/10.1371/journa 1 . pone. 0231924

[9] González-Sanguino C, Ausín B, Ángel Castellanos M, et al. Mental Health Consequences during the Initial Stage of the 2020 Coronavirus Pandemic (COVID-19) in Spain. Brain, Behavior, and Immunity. 2020; 87: 172-176. PMid:32405150. https://doi .org/10 $.1016 / j$.bbi.2020.05.040

[10] Henry JD, Crawford JR. The short-form version of the Depression Anxiety Stress Scales (DASS-21): Construct validity and normative data in a large non-clinical sample. British Journal of Clinical Psychology. 2005; 44(2): 227-239. PMid:16004657. https : //doi.org/10.1348/014466505X29657

[11] Bastien CH, Vallières A, Morin CM. Validation of the Insomnia Severity Index as an outcome measure for insomnia research. Sleep Medicine. 2001; 2(4): 297-307. https ://doi.org/10.1016/S1 389-9457 (00) 00065-4

[12] Demartini B, Nisticò V, D'Agostino A, et al. Early psychiatric impact of COVID-19 pandemic on the general population and healthcare workers in Italy: a preliminary study. Frontiers in Psychiatry. 2020; 11. PMid:33414728. https ://doi .org/10.3389/fpsyt. 2020.561345

[13] Zhang J, Lu H, Zeng H, et al. The differential psychological distress of populations affected by the COVID-19 pandemic. Brain, Behavior, and Immunity. 2020; 87: 49-50. PMid:32304883. https : //doi.org/10.1016/j.bbi.2020.04.031

[14] Wang C, Pan R, Wan X, et al. Immediate psychological responses and associated factors during the initial stage of the 2019 coronavirus disease (COVID-19) epidemic among the general population in China. International Journal of Environmental Research and Public Health. 2020; 17(5): 1729. PMid:32155789. https: //doi.org/10.3390/ijerph17051729

[15] Wang C, Pan R, Wan X, et al. A longitudinal study on the mental health of general population during the COVID-19 epidemic in China. Brain, Behavior, and Immunity. 2020; 87: 40-48. PMid:32298802. https://doi.org/10.1016/j.bbi.2020.04.028

[16] Ren Y, Zhou Y, Qian W, et al. Letter to the Editor "A longitudinal study on the mental health of general population during the COVID19 epidemic in China". Brain, Behavior, and Immunity. 2020; 87: 132133. PMid:32387510. https://doi.org/10.1016/j.bbi. 2020 .05 .004

[17] Robertson MM, Maynard WS, McDevitt JR. Telecommuting Professional Safety. 2003; 48(4): 30-36.

[18] Tavares AI. Telework and health effects review. International Journal of Healthcare. 2017; 3(2): 30. https://doi .org/10.5430/ijh. v3n2p30

[19] Kessler RC, McGonagle KA, Swartz M, et al. Sex and depression in the National Comorbidity Survey I: Lifetime prevalence, chronicity and recurrence. Journal of Affective Disorders. 1993; 29(2-3): 85-96. https : //doi.org/10.1016/0165-0327(93)90026-G

[20] Berg-Beckhoff G, Nielsen G, Ladekjær Larsen E. Use of information communication technology and stress, burnout, and mental health in older, middle-aged, and younger workers-results from a systematic review. International Journal of Occupational and Environmental Health. 2017; 23(2): 160-171. PMid:29460697. https : //doi.org/10.1080/10773525.2018.1436015

[21] Vega RP, Anderson AJ, Kaplan SA. A within-person examination of the effects of telework. Journal of Business and Psychology. 2015; 30(2): 313-323. https://doi.org/10.1007/s10869-014-935 9-4

[22] Parent-Thirion A, Vermeylen G, van Houten G, et al. Sixth European working conditions survey (EWCS). Office for Official Publications of the European Communities, Luxembourg, LU. 2015.

[23] Montreuil S, Lippel K. Telework and occupational health: a Quebec empirical study and regulatory implications. Safety Science. 2003; 41(4): 339-358. https://doi.org/10.1016/S0925-753 $5(02) 00042-5$

[24] Taylor MR, Agho KE, Stevens GJ, et al. Factors influencing psychological distress during a disease epidemic: data from Australia's first outbreak of equine influenza. BMC Public Health. 2008; 8(1): 347 PMid:18831770. https://doi.org/10.1186/1471-2458-8-3 47

[25] Shamir B, Salomon I. Work-at-home and the quality of working life. Academy of Management Review. 1985; 10(3): 455-464. https://doi.org/10.5465/amr.1985.4278957

[26] Grant CA, Wallace LM, Spurgeon PC. An exploration of the psychological factors affecting remotee-worker's job effectiveness, wellbeing and work-life balance. Employee Relations. 2013. https : //doi.org/10.1108/ER-08-2012-0059

[27] Vesala H, Tuomivaara S. Slowing work down by teleworking periodically in rural settings? Personnel Review. 2015. https ://doi or g/10.1108/PR-07-2013-0116

[28] Casey PR, Grzywacz JG. Employee health and well-being: The role of flexibility and work-family balance. The Psychologist-Manager Journal. 2008; 11(1): 31-47. https://doi.org/10.1080/1088 7150801963885

[29] Wittchen HU, Jacobi F, Rehm J, et al. The size and burden of mental disorders and other disorders of the brain in Europe 2010. European Neuropsychopharmacology. 2011; 21(9): 655-679. PMid:21896369. https ://doi.org/10.1016/j.euroneuro.2011.07.018

[30] Anderson AJ, Kaplan SA, Vega RP. The impact of telework on emotional experience: When, and for whom, does telework improve daily affective well-being? European Journal of Work and Organizational Psychology. 2015; 24(6): 882-897. https ://doi.org/10.1080/ 1359432X.2014.966086

[31] Irastorza X, Milczarek M, Cockburn W. Second European Survey of Enterprises on New and Emerging Risks (ESENER-2): overview report: managing safety and health at work. Publications Office of the European Union. 2016.

[32] Choi SW, Kim DJ, Choi JS, et al. Comparison of risk and protective factors associated with smartphone addiction and Internet addiction. Journal of Behavioral Addictions. 2015; 4(4): 308-314. PMid:26690626. https : //doi.org/10.1556/2006.4.2015.04 3

[33] King DL, Delfabbro PH, Billieux J, et al. Problematic online gaming and the COVID-19 pandemic. Journal of Behavioral Addictions. 2020; 9(2): 184-186. PMid:32352927. https ://doi .org/10.155 $6 / 2006.2020 .00016$ 